\title{
Principles and approaches of building the campus culture in the new period \\ Hailong SHAO ${ }^{1, a}$, Dongju DU $2, b$
}

\author{
${ }^{1}$ College of Engineering and Technology, Jilin Agricultural University, Changchun, 130118, China \\ ${ }^{2}$ College of Animal Science and Technology, Jilin Agricultural University, Changchun, 130118, \\ China \\ aemail: shaohailong1992@126.com, bemail:473352805@qq.com
}

Keywords: university; campus culture; university students

\begin{abstract}
As a form of culture, the campus came along with the emergence of the school. It is a comprehensive, multi-formed and multi-layered cultural phenomenon and a part of social culture. An increasing number of educators have realized that campus culture can become an important educational force and an important carrier of university education. In this paper, it is pointed out that more attention should be paid to cultivation, construction and development of university campus culture. This is of vital significance for university campus culture to realize the goal of developing talents with higher education.
\end{abstract}

\section{Introduction}

The concept of "university campus culture" was first mentioned by Waller, an American scholar, in his book, The Sociology of Teaching, in 1932. According to Waller's definition, "campus culture" is a special culture formed in school. He thought that university campus culture belongs to a sub-culture of social culture, which emerged along with schools.

Some domestic scholars think that campus culture specially refers to the spiritual life of university students after class, including ideas, literature and art, in universities. University students are subjects of university campus life. University campus culture reflects ideas of university students and demonstrates their internal world ${ }^{[1]}$. Some other researches expand the research scope of campus culture to the whole school, thinking that campus culture is an organic whole composed of material culture, spiritual culture, institutions and behaviors. Students, teaching and administrative staff form its carrier. Moreover, some scholars divide the subjective and objective relationship involved in campus culture, and define campus culture as all material and spiritual achievements jointly created by students, teaching and administrative staff in the field of teaching, learning, scientific research, administration and life with students and teachers at the center ${ }^{[2]}$. All the above definitions do not differ from each other greatly. Their major difference is the extension of subjects and objects involved in campus culture.

Therefore, the campus culture, especially the university campus culture, refers to the unique cultural connotation and spirit formed through the school, the system, and its operation. Different universities have different cultural connotations and spirits. This is the major cause of differences among various universities, and a major factor differentiating university campus culture from other social culture.

\section{Problems existing in university campus culture}

\section{Material problems}

Materially speaking, university campus culture consists of environmental culture, facility culture and manner culture. In terms of the environmental culture, since the increased enrollment of Chinese universities in 1999, many universities have launched a large-scale restoration and expansion so as to reach requirements of teaching conditions and teaching construction. However, being in a rush for quick results, they often ignore the building style, the garden art and the campus 
characteristics. In terms of facility culture, a large number of institutions related to management, teaching and logistics have emerged due to an increasing scale of enrollment. As a result, many institutions do things in their own way, leading to a low working efficiency ${ }^{[3]}$.

\section{Institutional problems}

Institutionally speaking, university campus culture consists of administration culture and organizational culture. In terms of management culture, universities are changing with each passing day, but administration systems are relatively backward, labor and responsibility distribution is unclear, thus resulting in a management chaos. In terms of organizational culture, some organizational activities try to please audiences with claptrap. Being impractical and mediocre, they seek quick returns. Consequently, university campus culture becomes increasingly dull and deviates from its essential pursuit, being lifeless.

\section{Spiritual problems}

The spiritual culture of campus culture is mainly reflected by ideological status of students, teaching and administrative staff, including value concepts, moral standards, way of thinking, emotional temperament, etc. In the current period, every university is shaping their own value concepts and moral standards. Behaviors of teachers and students are comprehensively integrated through the school motto, the school song, and the school badge. The spirit of schools is permeated in schools multi-dimensionally. In this way, campus culture with striking characteristics and a strong sense of era is created. However, as traditional behavioral standards are gradually abandoned, new social standards have not yet been fully established. Misconducts are everywhere to find. Values and moral standards are ignored. All these have seriously corroded the university campus spiritual culture. Students cannot learn honestly and teachers cannot teach honestly. Meanwhile, due to the strong impact of mass culture, campus culture is developing blindly without its own characteristics. Some students become shallow, blundering, sly and vulgar. They eve become spiritually empty, and lose sense of social responsibility and mission. The "herd" phenomenon directly influences and inhibits sound development of university campus culture ${ }^{[4]}$.

\section{Principles and approaches of building campus culture}

\section{Emphasize on shaping of the "scientific spirit"}

The scientific spirit advocated by campus culture features unremitting pursuit of truth, employment of logic and common sense or scientific methods to demonstrate and doubt and ability of self-reflection and criticism. All these qualities are lacking in Chinese campus culture. To the end, campus culture construction should reflect admiration of scientific and reasonable era requirements in various aspects.

\section{Emphasis on individual development}

The most striking characteristic of Western campus culture is individualism. Under the ideological orientation, Western campus culture regards students as subjects of campus culture, fully displaying and relying on their group energy. Various school associations keep emerging in Western campuses. Chinese campus culture construction should learn from the Western counterpart. Chinese schools should vigorously support development of student associations in various forms, allowing students to manage themselves and hold activities without administrative interventions.

\section{"Emphasis on both science and culture"}

The top priority of building and developing university campus culture is building and developing university spiritual culture. University spirit is a school running concept and a value pursuit. Harvard University persists on "exploring truth and learning as the core value of university." The school motto of Harvard University is "To be friends of Plato, of Aristotle and truth." First, truth, rational thinking and scientific practices should be advocated, and the scientific spirit and the cultural spirit should be closely combined. Second, insist on and pursue the academic value 
orientation of "academic freedom and academic democracy" and encourage different academic ideas and schools. An important symbol of academic democracy is to allow the existence of different ideas. Efforts should be intensified to creating an "inclusive, open and critical" campus culture atmosphere and a modern university campus spirit of "advocating science, encouraging innovation and tolerating differences.' Third, “advocate management democracy and govern schools with moral standards.” Teaching management should not only give full play to students' dominant role, thus forming a hot discussing atmosphere, a quorum sensing and a symbiotic effect to encourage students' innovational spirit, but also stimulate students' creativity by creating a tolerant and democratic talent development environment highlighting personality. In this way, students will be motivated to bring out the best in them, contributing to promotion of innovational awareness and abilities.

\section{Building of personality culture}

Building and developing university culture relies on building and developing personality culture. University personality culture refers to the unique characteristics giving an edge for a school over another and which are formed through long-term school running. During the school reform and development, especially during optimization of talent development and improvement of educational quality, it plays an important role. As an important part of university culture, motto is a highly-condensed summary of a school's operation concept, talent development requirements and spiritual culture. It is a flag which encourages and calls up teachers to focus on academic research and teaching, and students to commit themselves to their learning and dreams. It is also the pursuit of a school. Only in when universities develop cultures with their own characteristics can diversified university cultures be formed and talents of different layers, types, styles and skills be developed to meet diversified talent demands of society ${ }^{[5]}$.

Development of innovational culture

An innovational institutional culture is one which is attractive, ready to accept novel things and ideas, tolerant and inclusive. To build the modern university institution means to put contemporary university spirit (including pursuit of science, advocacy of truth, academic freedom, encouragement of innovation, rational criticism and cooperation and competition) in the form of institutional culture, and carry forward it; to advocate a favorable school atmosphere featuring hard-work, courage of innovation, devotion to research and prudence; to build an innovational culture featuring contention of a hundred schools of thought, encouragement of innovation and toleration of failures; to stick to academic morals, overcome fickleness and academic frauds, and create a democratic, open, forward-looking and harmonious academic environment and atmosphere. In a word, all cultural and institutional obstacles impeding development of innovational talents and realization of innovational achievements should be eliminated.

\section{Conclusions}

The long-term development of a school relies on the virtuous circle of campus culture construction. Therefore, universities should enhance their efforts to maximize the potentially positive influence of campus culture on students' qualities.

\section{References}

[1] WEN Huiping. On university campus culture[J]. Journal of Fuzhou University (Philosophy and Social Sciences Edition), 2004 (4).

[2] SHI Huanan \& HU Min. On several basic issues of campus studies[J]. Journal of Yangzhou University (Higher Education Study Edition).2000 (3).

[3] YANG Chen. On the role of campus culture construction in cultural innovation[J]. Journal of Higher Correspondence Education(Philosophy and Social Sciences),2014(4). 
[4] LIANG Wenying. The role of campus culture in the growth and development of College Students [J]. Journal of Hubei University of Economics(Humanities and Social Sciences),2012(5).

[5] WANG Xiangdong. On the role of campus culture construction in the discipline construction of Universities [J]. China Adult Education,2014(20). 